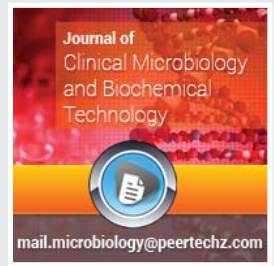

\title{
Colonic perforation in 91- year- old man with severe Covid-19 infection
}

\author{
Khin Phyu Pyar*, Min Aung Shan, Soe Win Hlaing, Diwon, \\ Zarni Htet Aung, Soe Min Aung, Nyan Lin Maung and Aung \\ Phyoe Kyaw
}

Department of Medicine, Defence Services Medical Academy, Mingalardon 11021, Myanmar

Received: 10 December, 2020

Accepted: 23 December, 2020

Published: 24 December, 2020

*Corresponding author: Khin Phyu Pyar, Department of Medicine, Defence Services Medical Academy, Mingalardon 11021, Myanmar,

E-mail:khinphyupyar@gmail.com

Keywords: Covid-19; Severe; Pneumoperitoneum; Colon perforation

https://www.peertechz.com

\section{Check for updates}

\section{Case summary}

A-91-year old man had severe Covid-19 infection (bilateral pneumonia, SaO2 85\% on air). He was treated with antibiotics, oxygen, dexamethasone and convalescent plasma therapy. On day 28 symptom onset, he noticed abdominal distension without abdominal pain. CT abdomen revealed pneumoperitoneum. An area of perforation at colon with mucosal haemorrhage was seen in laparotomy. Right hemicolectomy was done. Histology showed mucosal oedema, infiltration with inflammatory cells mainly polymorphs and lymphocytes, congested vessels with areas of haemorrhage in the mucosa.

\section{Introduction}

The novel coronavirus disease, caused by the severe acute respiratory syndrome coronavirus 2 (SARS-CoV-2), has spread world-wide since 2019 December. Over 62.5 million people have Covid-19 infection and 1.44 million died from severe infection [1]. The mortality rate is also high in elderly [2], those having co-morbid states like diabetes, hypertension, heart failure, $\mathrm{COAD}$, end stage renal disease, immunosuppressant therapy. The cause of death is ARDS, multi-organ failure and pulmonary embolism. Although gastrointestinal symptoms are not uncommon, colonic perforation is very rarely reported.

\section{Clinical presentation}

A-91-year old man had fever, cough with dyspnoea for 7 days and was brought to hospital. He was previously healthy and lived with caring family. He did not have dementia and was ambulating well. He was not diabetics nor hypertensive. His nasopharyngeal swab for Covid-19 PCR was positive. His $\mathrm{SaO} 2$ on air was $83 \%$ and respiratory rate was $28 /$ minutes. Chest Xray was consistent with severe pneumonia as patchy opacities occupied more than $50 \%$ of lung parenchyma on both sides (Figure 1(a)). His total WBC was $31.6 \mathrm{X} 10^{\%} / 1$ and absolute lymphocyte count was $2.2 \mathrm{X} 10^{9} / 1$. He had high LDH
(1262 U/L), high CRP (297.94 mg/l) and serum creatinine was marginally raised $(1.6 \mathrm{mg} \%)$ Thus, he was treated as a case of severe Covid-19 infection with oxygen 10L/min, imipenem, azithromycin, dexamethasone, low molecular weight heparin, vitamins and dexamethasone. Convalescent plasma therapy was given on Day 12 symptom onset.

He made gradual improvement over one weeks. His symptoms improved on Day 14 symptom onset. Absolute lymphocyte count decreased to $1.5 \mathrm{X} 10^{9} / 1$ and Chest Xray too

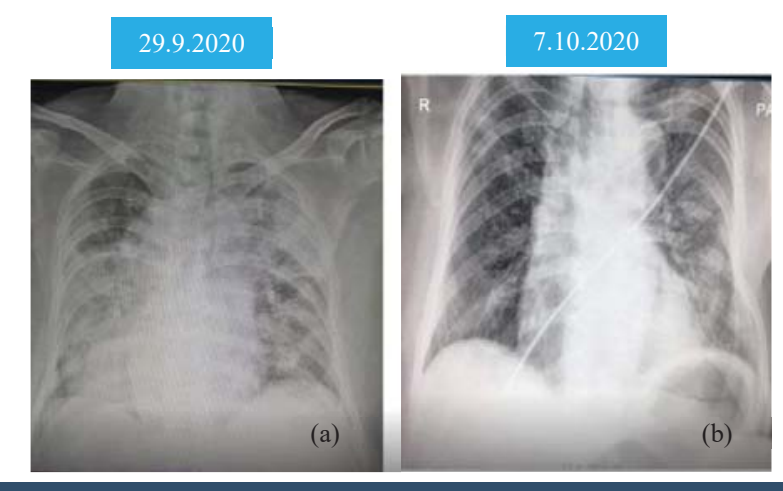

Figure 1: (a) and (b) Serial CXR. 
(Figure 1(b)). His nasopharyngeal swab for Covid-19 PCR was negative on Day 15 symptom onset.

$\mathrm{SaO} 2$ was $95 \%$ on air on Day 21 symptom onset. His appetite was apparently good and he was on normal diet. His antibody level after plasma therapy was better. IgG level rose from 4.33 $\mathrm{mg} / \mathrm{dl}$ to $16.46 \mathrm{mg} / \mathrm{dl}$ and IgM level from $1.02 \mathrm{mg} / \mathrm{dl}$ to 1.68 $\mathrm{mg} / \mathrm{dl}$. LDH level dropped (358U/L) and CRP also ( $58 \mathrm{mg} / \mathrm{l})$. His total WBC became 16.89 X10 $9 / 1$. But absolute lymphocyte count dropped i.e., $0.33 \mathrm{X} 10^{9} / 1$.

On Day 24 symptom onset, he had loose motion (2 to 3 times per day). There was no abdominal pain or vomiting. There was no blood or mucus in stool. Then he noticed abdominal distension gradually and discomfort. On Day 28 symptom onset, there was features of peritonism on examination. CT abdomen revealed massive free gas and oedematous colon on right side (Figure 2). Later, he developed fever and blood pressure dropped. Inotropes, metronidazole and fluid and electrolytes were given.

Laparotomy was done under general anaesthesia. There was free air and a small area of perforation $(0.8 \mathrm{~mm})$ in ascending colon. On cut section, mucosal congestion with submucosal haemorrhagic areas were seen. There was no growth or ulcer. There was no pseudo-membrane (Figure 3).

Right hemicolectomy and peritoneal toileting were done. Drainage tube was inserted. Histology showed mucosal oedema, infiltration with inflammatory cells mainly polymorphs, lymphocytes, few plasma cells and histiocytes. Congested vessels with areas of haemorrhages in the mucosa (Figure 4). Organisms, granuloma, cellular and nuclear atypia are not found.

Both intra-operative and immediate post-operative period were very critical. His $\mathrm{SaO} 2$ dropped and ventilatory support, two inotropes, blood transfusion and fluids were given. Then, features of ARDS set in (Figure 5). Two days later, his condition deteriorated more and expired.

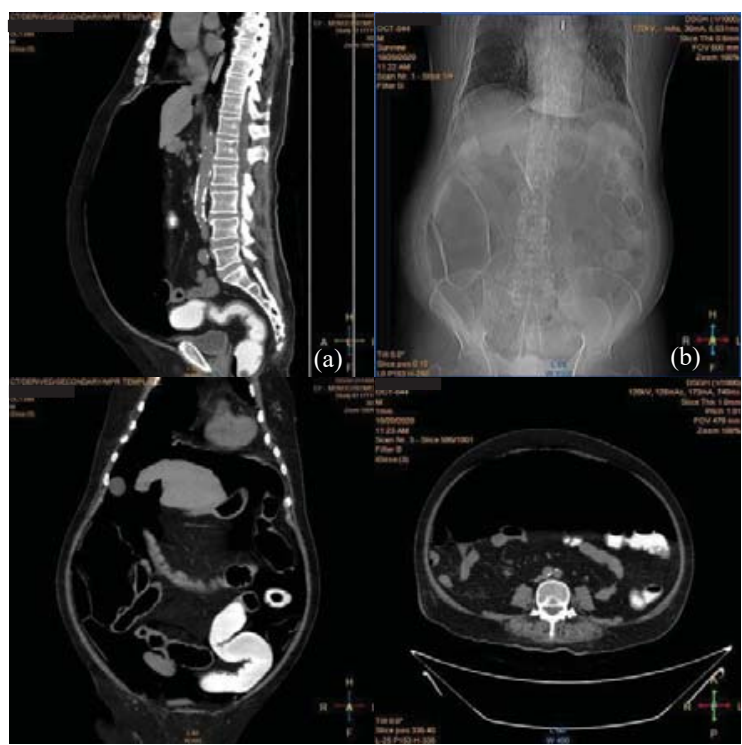

Figure 2: СT Abdomen showing dilated colon \& pneumoperitoneum.

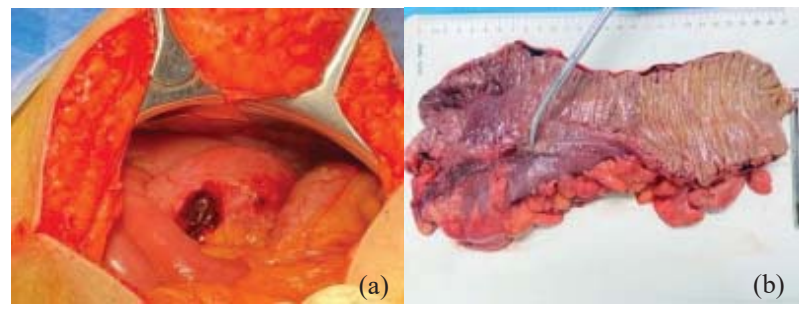

Figure 3: Laparotomy findings \& mucosal haemorrhage in cut section of colon.

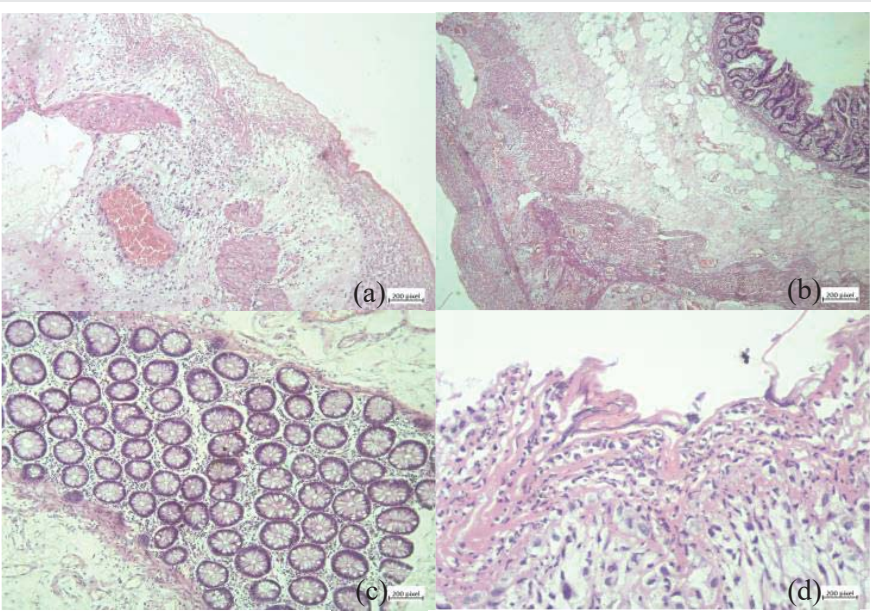

Figure 4: Histological section taken from right hemicolectomy specime.

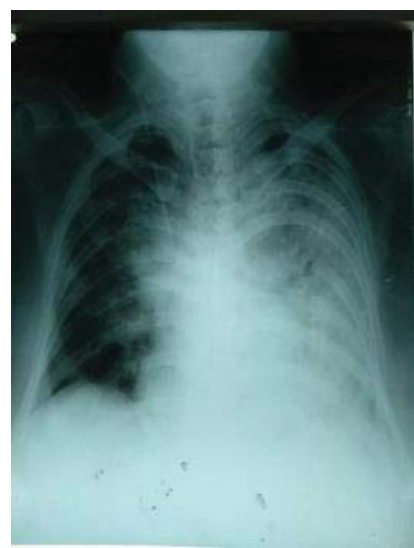

Figure 5: CXR showing ARDS.

\section{Discussion}

Covid -19 infection has over all mortality rate of $5 \%$ in all age group and it is high in older age, those having comorbidities like diabetes, hypertension, heart failure, COAD, end stage renal disease, immunosuppressant therapy [2]. In this case, apart from very old age of 91 year, there is no other medical diseases.

Several studies mentioned that gastro-intestinal manifestation is found in $10-20 \%$ of Covid-19 infection $[3,4]$. One of the reports mentioned identification of Covid-19 virus in the mucosa of gastrointestinal tract. They proved that SARS-CoV-2 RNA detection and intracellular staining of viral nucleocapsid protein in gastric, duodenal, and rectal epithelia in patients with Covid-19 infection [5]. 
An atypical manifestation of colonic perforation in patient with Covid-19 infection was mentioned in one report. The patient was a-80-year old female. She presented with both respiratory and abdominal symptoms. And she had pneumothorax and acute perforated abdomen [6].

The report from Italy also mentioned a case of colonic perforation which was diagnosed on 10 day of hospitalization. The patient was a -53- year old male, hypertensive with severe Covid-19 infection, presented with multi-organ failure [7]. The findings in CT abdomen was similar to our case.

Another case was a -34 - year man, obese (BMI 36), with severe Covid-19 infection. He got occult colonic perforation following interleukin - 6 receptor antagonist therapy. They identified SARS-CoV-2 virions in the colon by electron microscopy [8]. In their description, abdominal examination did not reveal features of peritonitis i.e., similar to initial findings of our case. The intestinal complication involving both small and large intestine was also recognized in a patient with Covid-19 infection who received treatment with tocilizumab. He was 43 year and he had ulceration in ileum with colitis and ileal perforation [9]. They assumed that the possible relationship between even a single dose of tocilizumab and gut ulceration in Covid-19 populations needs further investigation. [9]. In our case, the patient did not receive interleukin - 6 receptor antagonist therapy.

In Covid-19 infection, elderly population with comorbidities are found to develop more complications [2]. Thus, their mortality is higher than others. L Marco and et al highlighted acute intestinal manifestations in Covid-19 patients and they pointed out the awareness among them. There are other reports too [10]. Kangas-Dick, et al. [11] also reported a case of duodenal perforation in Covid-19 case with severe pneumonia.

The possible mechanism of injury is interesting. One way is direct infiltration of colonic cells by Covid-19 virus. It was proved in earlier study where they found Covid-19 virus in rectal mucosa in addition to oesophagus and gastric mucosa [5] In this case, we did not do viral RNA in histological specimen or stool. Another mode of injury is due to autonomic neuropathy of colon as a result of Covid-19 related neuronal injury [7,12].

\section{Conclusion}

In Covid-19 pandemic era, though the common presentation is mainly fever, cough and dyspnoea, awareness of abdominal symptoms is also important. It may be initial presentation or late - 28 days symptom onset in this case. Colonic perforation is a very rare complication. It may develop as a result of direct viral invasion or virus-related neuronal injury causing colonic stasis. It may be due to complication of interleukin -6 receptor antagonist therapy.

\section{Acknowledgements}

The authors would like to thank the patient and his family for giving consent to this article. Also, to all doctors and nursing team for making great efforts in caring him. The authors acknowledged the following team; Dr Kyaw Htet and his surgical team, Prof Yu Aye Latt and her anaesthetic team, Dr Chan Myae and his intensive care team, Prof Ko Ko Lwin, Prof Kyaw Zay Ya, Prof Myint Zaw and Dr Zaw Myo Han for administrative support, Prof Tin Moe Mya, Dr Tin Tin San and Dr Kyaw Wunna for laboratory support, Dr Hein Htet Oo, Dr Aung Aung and Dr Kyaw Zaya for convalescent plasma therapy and Dr Swan Htet for microbiological support.

\section{Informed consent}

The informed consent for publication in this article was obtained from patient family.

\section{References}

1. WHO (2020) WHO Coronavirus Disease. WHO.Int. Link: https://bit.ly/2KPOybl

2. Ciceri F, Castagna A, Rovere-Querini P, De Cobelli F, Ruggeri A, et al. (2020) Early predictors of clinical outcomes of COVID-19 outbreak in Milan, Italy. Clin Immunol 217: 108509. Link: https://bit.ly/2Kwyonu

3. Jin X, Lian JS, Hu JH, Gao J, Zheng L, et al. (2020) Epidemiological, clinical and virological characteristics of 74 cases of coronavirus-infected disease 2019 (COVID-19) with gastrointestinal symptoms. Gut 69: 1002-1009. Link: https://bit.ly/3pfxCtC

4. Nobel YR, Phipps M, Zucker J, Lebwohl B, Wang TC, et al. (2020) Gastrointestina Symptoms and Coronavirus Disease 2019: A Case-Control Study From the United States. Gastroenterology 159: 373-375.e2. Link: https://bit.ly/3pfxNFi

5. Xiao F, Tang M, Zheng X, Liu Y, Li X, et al. (2020) Evidence for Gastrointestinal Infection of SARS-CoV-2. Gastroenterology 158: 1831-1833.e3. Link: https://bit.ly/3mHGx5H

6. Corrêa Neto IJF, Viana KF, Silva MBS, da Silva LM, da Oliveira G, et al. (2020) Perforated acute abdomen in a patient with COVID-19: an atypica manifestation of the disease. Journal of Coloproctology 40: 269-272. Link: https://bit.ly/3alJWyD

7. De Nardi P, Parolini D, Ripa M, Racca S, Rosati R (2020) Bowel perforation in a Covid-19 patient: case report. Int J Colorectal Dis 35: 1797-1800. Link: https://bit.ly/3aCWwzk

8. Schwab K, Hamidi S, Chung A, Lim RJ, Khanlou N, et al. (2020) Occult Colonic Perforation in a Patient With Coronavirus Disease 2019 After Interleukin-6 Receptor Antagonist Therapy. Open Forum Infectious Diseases 7. Link: https://bit.ly/38xOCojx

9. Bruce-Hickman D, Sajeed SM, Pang YH, Seow CS, Chen W, et al. (2020) Bowel ulceration following tocilizumab administration in a COVID-19 patient. BMJ Open Gastroenterol 7: e000484. Link: https://bit.ly/38smaUS

10. Winnicka LM, Shenoy MA (2020) Gastrointestinal Perforation in a COVID-19 Patient. Infectious Diseases in Clinical Practice 28. Link: https://bit.ly/34lxJpM

11. Kangas-Dick A, Prien C, Rojas K, Pu Q, Hamshow M, et al. (2020) Gastrointestinal perforation in a critically ill patient with COVID-19 pneumonia. SAGE Open Medical Case Reports 8: 2050313X20940570. Link: https://bit.ly/37J4gOo

12. Lotti M, Giulii Capponi M, Magnone S, Campanati L, Lucianetti A (2020) Beware of the acute bowel disease in COVID-19 patients. ANZ Journal of Surgery 90: 2586-2588. Link: https://bit.ly/3nQcKcf 